\title{
Management of Municipal Solid Waste in Sri Lanka: A Comparative Appraisal of the Economics of Composting
}

\author{
T Lalithasiri Gunaruwan and W Neluka Gunasekara
}

\begin{abstract}
Sri Lanka, a developing nation, is facing a severe problem of Municipal Solid Waste (MSW) management, the currently adopted predominant method being open dumping due mainly to low cost and less processing involved. This practice is hazardous, and causes significant negative externalities to society and to the economy. In contrast, composting is considered to be one of the most technically appropriate methods of managing MSW in Sri Lanka, the composition of waste being predominantly organic. Though a few local authorities are engaged in composting but no comprehensive economic feasibility study has been carried out which is the knowledge gap that this paper attempts to address. The study examined the economics of MSW management through composting in Sri Lanka by examining various models proposed and implemented. Further, the Pilisaru prescription and what has been implemented by a few local authorities were analysed using benefit-cost appraisal methodology, with particular reference to the management model adopted by the Weligama Urban Council. The study reveals that composting as a MSW management method would be economically viable. It also signifies that based on comparative investment and operating cost levels in other composting experiments in Sri Lanka, even achieving financial viability would be possible, if a compost management model with improved investment productivity is developed.
\end{abstract}

Keywords: composting, economic viability, environmental safeguarding, municipal solid waste management.

JEL Classification Codes: D61, D62, H23, H43, O13, O18, Q53, Q56

T Lalithasiri Gunaruwan, $\boldsymbol{P h D}$ is a Senior Lecturer of the Department of Economics, University of Colombo. E-mail: tlgun@econ.cmb.ac.lk (Corresponding author)

W Neluka Gunasekara is a Research Assistant at the Institute of Policy Studies, Sri Lanka. 


\section{NSBM Journal of Management}

Vol. 2, No. 1, January - June, 2016

\section{Introduction}

With increasing urbanization, managing municipal solid waste has become a major problem in the developing world. Sri Lanka is no exception. Population growth and per capita income growth have raised the issue to a different scale (with disproportionately heavy generation of waste) and technological complexity (with changes in the composition of waste). Local authorities, statutorily responsible for the management of waste generated within their respective boundaries, are currently practising 'open dumping' as a means of waste disposal in spite of the health hazards and negative environmental impact of that methodology. Open dumping also implies very high opportunity cost as it deprives vast extents of valuable municipal land unavailable for more productive use.

In this light, it is widely accepted that an appropriate and affordable municipal waste management system should be adopted by the local authorities in Sri Lanka. Composting becomes an alternative solution in this milieu particularly because the technology involved is simple and suits the nature of Sri Lanka's municipal waste, which is still largely organic ${ }^{1}$. A significant share of the economy consisting of agricultural activity would imply availability of a ready market for compost as a soil conditioning input. However, except for a few local authorities, the majority of local bodies are yet to undertake composting on a large commercial scale.

The economics of composting, which is largely unknown, could well be the cause. It might be the missing link in the decision making chain that prevents local authorities from considering composting as an option for dealing with the problem of waste management. Filling this research gap is the focus of this study.

It was conceived with the objective of appraising the economics of managing Sri Lanka's municipal solid waste using composting technology. This paper summarises the procedural approach, methodology adopted, results obtained and their management and policy relevance. The scale of the municipal solid waste problem and its environmental and socio-economic

\footnotetext{
Almost all the scientific and technical literature refers to Sri Lanka's municipal solid waste as being substantially organic and having a high moisture content as the following shows: "MSW of Sri Lanka typically consists of a very high percentage of perishable organic material which is about $65-66 \%$ by weight with moderate amounts of plastic and paper and low contents of metal and glass. The moisture content of MSW is also very high in the range of $70-80 \%$ on a wet weight basis" (Bandara, 2008); “...Primary components on a weight basis are compostable organics; food and garden waste accounting for 89.2\%" (Wijerathna, et al., 2012); and "...Sri Lankan MSW consists of $54.5 \%$ short-term bio-degradable waste .... and $5.9 \%$ Long term bio-degradable waste" (Hikkaduwa, et al., 2015).
} 
Management of Municipal Solid Waste in Sri Lanka: A Comparative Appraisal of the Economics of Composting

implications are discussed through literature based on both Sri Lankan and international experience. The appropriateness of composting as a municipal solid waste management methodology in Sri Lanka is examined through relevant case examples from cities in the regional countries. The methodology adopted, namely, the benefit-cost evaluation approach, the analytical process and results are discussed, and comparative decision criteria for economic and financial viability of municipal solid waste management through composting are developed. The practicality and economic feasibility of different management models developed for the purpose and practised by various local government authorities are also comparatively examined. Finally, the study aimed at proposing strategies to be considered by the authorities to make the Sri Lankan urban environment greener and healthier.

\section{Solid Waste Problem, Management Practices and Implications: A Literature Survey}

\section{Waste Generation and Determinants}

Municipal solid waste management is recognised as a problem not only in Sri Lanka but also in many other urbanising townships in the developing world. The problem is particularly significant where the urban population share and density are relatively high and increasing fast. For instance, in developing Asian countries, where the urban population share is around $35 \%$ (for example, China and Thailand ${ }^{2}$ ) and still growing at a rate of around $4 \%$ per year, and also in those less developed Asian economies, where population densities are high and increasing, the issue has become acute (Glawe, et al., 2005). The rapid economic growth in these countries has aggravated this problem as it has led to improved standards of living and to changed consumption patterns of people, resulting in increasing per capita waste generation levels, currently ranging from 0.2 to $1.7 \mathrm{~kg}$ per day (Visvanathan \& Trankler, 2003). India's present waste generation, around 0.2-0.5 kg per day, for instance, is eight times higher than what it was in 1947, and continues to grow at an annual rate between 1 and 1.33 per cent (Sharholy, et al., 2008). Mumbai, the Indian city with the highest per capita waste generation of $0.5 \mathrm{~kg}$, produces 6256 metric tons of garbage per day (Yedla \& Kansal, 2003).

Sri Lankans generate approximately $0.62 \mathrm{~kg}$ of solid waste per day on average (Visvanathan $\&$ Trankler, 2003). This rate varies depending on the income levels of individuals and households as well as on the degree of urbanization of settlements. Low-income households, for instance, generate half a kilogramme of garbage per day while high-income groups

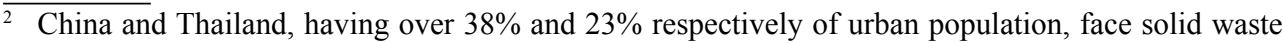
problems. 


\section{NSBM Journal of Management}

Vol. 2, No. 1, January-June, 2016

average nearly double that (Asian Institute of Technology, 2004). Having studied the solid waste management patterns in the Pinga Oya environs (Harispattuwa, Akurana, Pujapitiya and Patha Dumabara) in Kandy suburbs, Mahees et al. (2011) came out with a linear function to explain per capita solid waste generation (in grammes) in terms of weekly expenditure on food, where every rupee of additional expenditure would be associated with 0.142 grammes of additional solid waste generation. Colombo, the commercial capital and the most urbanized city, is the largest producer of solid waste in Sri Lanka (Bandara, 2008).

\section{Waste Management: Current Practices, Costs and Environmental Implications}

As at present, management of municipal solid waste in Sri Lanka, collection to treatment, is not at an accepted level. Only a fraction of the total municipal solid waste generated in Sri Lanka is collected by the local authorities ${ }^{3}$. For instance, according to the National Solid Waste Management Report for 2007 of the Japan International Cooperation Agency (JICA), the total amount of garbage collected in 311 local authorities was 2838 metric tons per day (NSWMSC, 2008), which amounts to an annual garbage collection of 1.04 million metric tons per year. This is a mere $23 \%$ of the total garbage generation even though the rate of waste collection to generation in the three main Municipal Councils in the Colombo District, namely, Colombo, Dehiwala-Mount Lavinia and Sri Jayewardenepura Kotte, could be as high as $30 \%-40 \%$ (Bandara, 2008). Out of the total daily waste collection in the country, nearly $59 \%$ is collected within the Western Province while Colombo District accounts for over 44\% (NSWMSC, 2008).

The current practice in managing municipal waste in Sri Lanka, as much as in other developing Asian countries, is 'open dumping' with little or no treatment by the local authorities (Glawe, et al., 2005); (Sharholy, et al., 2008); (Bandara, 2008). Sri Lanka has a number of large-scale open dumpsites around the capital city for Colombo's waste but has never had

\footnotetext{
As most research and surveys have gathered data on waste collection and not on total waste generation, no consensus could be found among various estimates with regard to the latter. For instance, the Western Provincial Council's Waste Management Authority estimates it to be between 6500 MT to 7000 MT per day (Mannapperuma, n.d.); their per-capita daily waste generation estimate between $0.4 \mathrm{~kg}$ and $1 \mathrm{~kg}$, however, would prompt at a much higher amount of total waste generation in the country. Bandara (2008) speaks of a per-capita waste generation ranging from $0.4 \mathrm{~kg}$ per day (in Pradesheeya Sabhas) to $0.75 \mathrm{~kg}$ per day (in Municipal Council areas) while Colombo Municipality would be producing $0.85 \mathrm{~kg}$ per day. This implies that the total waste generation in Sri Lanka would be between 8000 MT and 15000 MT per day, and an average garbage production of 12400 MT per day or approximately 4.5 million MT per year at an average waste generation intensity of $0.62 \mathrm{~kg} /$ person/day. Nevertheless, there is no disagreement on the contention that the collection by the local authorities would only be a fraction of the generation, which would not be half of even the lowest possible generation estimate.
} 
a full-scale sanitary landfill site ${ }^{4}$. This unscientific and unsanitary practice has resulted in a number of environmental and health hazards in both developing and least developed Asian countries, largely owing to the high organic composition of the waste (Glawe, et al., 2005); (Visvanathan \& Trankler, 2003); (Sharholy, et al., 2008). In South India, for instance, a considerable proportion of municipal waste consists of organic matter such as banana leaves and stems (Sharholy, et al., 2008) while the organic content of municipal waste in highly urban cities such as Mumbai is of significant proportions (Yedla \& Kansal, 2003). Local authorities in Sri Lanka are no exception; there is a very high percentage of organic matter in the waste even in highly urbanised areas (Bandara, 2008). ${ }^{5}$ High organic matter coupled with high moisture content in the waste, as observed in Sri Lanka, leads to highly polluting leachate causing surface and groundwater pollution (Pilapitiya, 2012). ${ }^{6}$

The Sustainable Solid Waste Landfill Management in Asia Project identified 199 cases of water-borne diseases and 22 cases of dengue in 2001, and also the possible effect on the quality of water in urban water supply intake zones (Asian Institute of Technology, 2004). Unacceptably high acidic levels have been found in ground water at a former solid-waste dumpsite in Sri Lanka; even the samples obtained from the vicinity of this locality had chemical oxygen demand levels far in excess of tolerance limits (Bandara \& Hettiaratchi, 2010). The National Water Supply and Drainage Board has found that the ground water aquifers in the greater Colombo area is polluted, primarily because of open dumping of solid waste, and thus unsuitable for use as a source of drinking water supply (NSWMSC, 2008). The opportunity cost of finding alternatives would indicate the measure of environmental damage caused by the unscientific dumping of solid waste in and around Colombo (Asian Institute of Technology, 2004). ${ }^{7}$ Open solid waste dumps also are a primary source of greenhouse gases such as methane and carbon dioxide, leading to air pollution and to climate

$\overline{4}$ A pilot scale sanitary landfill site, funded by KOICA, is now in operation at Dompe, Sri Lanka.

5 According to Bandara (2008), MSW of Sri Lanka typically consists of a very high percentage of perishable organic material which is about $65-66 \%$ by weight. The highest share of plastics, Glass and Metal together of $18 \%$ was reported from Jaffna and Trincomalee cities while Colombo and Matara recording the lowest with $11 \%$ and $12 \%$, respectively. While different surveys and research have come out with varying estimates, and in spite of the variability of organic share according to the type of local authority (whether they are Municipal Councils, Urban Councils or Prasesheeya Sabhas), the general consensus could be observed among solid waste technologists that Sri Lankan municipal solid waste contains relatively high share of organic and bio-degradable composition.

${ }^{6}$ Information and technical guidance provided by Dr. Sumith Pilapitiya, Environmental specialist, The World Bank, are hereby thankfully acknowledged.

7 NWSDB had to augment Greater Colombo's water supply from the Kalu Ganga at a cost of Rs. 8.3 Billion. 


\section{NSBM Journal of Management}

Vol. 2, No. 1, January - June, 2016

change (Pilapitiya, 2012). In Sri Lanka, high levels of odour, dust and toxic fumes have been found emanating from uncontrolled burning of solid waste (Asian Institute of Technology, 2004). Haphazard dumping also results in the loss of wetland habitats, which impacts on fauna and flora (particularly in Attidiya and Muthurajawela areas), loss of aesthetic value and associated socio-economic effects, flooding, and exposure to clinical and industrial waste (NSWMSC, 2008). ${ }^{8}$ High degrees of rainfall and humidity aggravate the problem of environmental damage (Glawe, et al., 2005).

In spite of the highly unhygienic and unscientific nature of the present methodology of handling waste, the country spends a significant amount of resources daily on it. An estimation made in 2004 revealed that solid waste management expenditure ranges from a high Rs. 2000 per metric ton in a Municipal Council to a low Rs. 1,200 per metric ton in an Urban Council. Pradesheeya Sabhas, on average, spend an amount in between (Waste Management Authority, 2013). Thus, it could be estimated that the country spends substantially on the daily collection and disposal of garbage (an amount between 1.2 to 2 billion rupees) not to speak of the cost of the harm to the environment.

\section{Alternative Methodologies: Technical Appropriateness of Composting}

It is in this context that better and environmentally sound solid waste management methods are urgently needed. Many such methods such as sanitary land filling or incineration, for instance, are expensive or impracticable given the socio-economic parameters prevailing in the developing countries and also the composition of waste. Incineration would not work with municipal solid waste in developing countries such as Sri Lanka due to high moisture content and low calorific value caused by the predominantly organic nature of the waste (Glawe, et al., 2005); (Visvanathan \& Trankler, 2003); (Sharholy, et al., 2008); (Yedla \& Kansal, 2003); (Bandara, 2008). It also entails high capital, operational and management costs (Asian Institute of Technology, 2004). For these reasons, incineration is feasible only with special types of waste. The practice in India of incinerating hospital waste could be cited as an example (Sharholy, et al., 2008); (Yedla \& Kansal, 2003). Sanitary land filling is a sophisticated method of waste disposal, and is more appropriate for developed countries. This is because of the high technology needed (Sharholy, et al., 2008) to prevent leachate seepage and to control gas emission when decomposing (Visvanathan \& Trankler, 2003). Sanitary land filling is highly capital- and operational cost-intensive, calling for high tolls on citizens for the removal of their garbage (if commercially operated) or an increased burden

8 In Bangladesh, open dumpsites are commonly found in low lying areas, and cause flooding during rainy seasons (Glawe, et al., 2005) 
on the public coffers (if the sites are publicly funded and freely provided). In addition, the amount of waste collected by the local authorities in most parts of Sri Lanka makes sanitary landfills economically unviable ${ }^{9}$ unless the collections by many local authorities are managed together to benefit from economies of scale. This implies that a sanitary landfill in Sri Lanka could become economically viable only in the Colombo metropolitan area. This was among the reasons why technology is unaffordable for Sri Lanka and other low-income developing countries with similar waste generation characteristics.

A three-pronged strategy, namely, recycling what is reusable with a resale value, composting the organic fraction of the waste and controlled land filling the residues, has therefore been proposed by technical experts as a potentially feasible strategy package to manage the solid waste problem in developing countries (IGES - Kitakyushu Urban Centre, 2011). Recycling and reusing help minimising the waste that has to be finally managed, and in that respect, is an appropriate and sustainable waste management technique with both environmental and direct financial benefits. ${ }^{10}$ And, a final waste treatment and disposal method is still necessary even though the scale of the problem could be reduced through recycling.

Composting is a 'win-win' strategy. It is technically one of the most suitable methods of waste treatment due to the high percentage of organic content in municipal waste collected in the less developed Asian countries (Glawe, et al., 2005); (Visvanathan \& Trankler, 2003); (Sharholy, et al., 2008). In addition to stabilising the organic fraction of the waste, composting also produces a soil conditioner with agronomic benefits that is a commercially marketable and economically useful product. It also helps to reduce the amount of garbage that has to be disposed, significantly reducing the pollution potential and volume of the residual waste for land filling. This has prompted many developing countries in Asia to use composting in managing their municipal solid waste. In Dhaka, Bangladesh, for example, composting is done largely as a small-scale industry while it is a home-based industry in the Maldives. India offers examples of successful large-scale composting initiatives (NSWMSC, 2008), including the Indore City Centre for MSW Composting established in 1974 (Sharholy, et al., 2008), and the large-scale aerobic facility installed in 1994 at Mumbai to handle 500 metric tons of municipal solid waste by Excel Industries with the support of the Government of

975 per cent (or 230) of the Local Authorities collect less than 5 MT per day, while another 17 per cent collect between 5 to 20 MT daily. Only 0.65 per cent of the Local Authorities collect over $150 \mathrm{MT}$ per day.

${ }^{10}$ It is mostly carried out by the informal sector (Glawe, et al., 2005), and is effectively practised in Thailand and India (Visvanathan \& Trankler, 2003). In India 40\%-80\% of recycled waste is plastic material. In Cambodia and Bhutan, $12 \%$ and $20 \%$ respectively of waste is recycled (Sharholy, et al., 2008). 


\section{NSBM Journal of Management}

Vol. 2, No. 1, January - June, 2016

India. By $2008,9 \%$ of the MSW in India was treated through composting (Sharholy, et al., 2008). The overall cost of production per metric ton was from US dollars 25 to 30 while the market value was from US dollars 33.5 to 42 per metric ton. India is planning to set up more plants in the near future (Visvanathan \& Trankler, 2003).

Although there are no large-scale commercial composting plants in Sri Lanka, many local authorities (such as Weligama, Balangoda, and Bandarawela) have been successfully running their own mini composting plants for some time. Approximately, 115 local authorities (including Kuliyapitiya, Tissamaharama, Chilaw, Tangalle, Wennappuwa, Buttala, Moneragala, Anamaduwa, Kalpitiya, Kinniya, etc.), have been recently provided with the infrastructure for composting through the Pilisaru Project of the Ministry of Environment, and are in various stages of construction and operation of their municipal waste composting facilities.

\section{Data and Methodology}

In this backdrop, the present study examined the comparative economics of municipal solid waste management models adopted in Sri Lanka. The Benefit-Cost Appraisal Methodology was adopted, where financial appraisal was conducted in order to discover the appeal of composting as an alternative waste management method for municipalities and an economic analysis was performed to understand the viability of the technology from the national economic viewpoint.

Technical and operational information and the cost data required for the analysis were gathered from secondary sources while interviews with municipal officials, officials of the United Nations Environment Programme, experts in the field of solid waste management, and officials of the Pilisaru Project (Project Officers, 2012) ${ }^{11}$ of the Central Environment Authority of Sri Lanka were conducted to gather primary data.

The study examined the model adopted by the Weligama Urban Council ${ }^{12}$ as against the 'Pilisaru' design proposed by the central authorities to accommodate approximately 18 metric tons of solid waste per day, to evolve comparative viability parameters. A few other technically successful experiments, particularly those conducted at Balangoda, Bandarawela and Kuliyapitiya, also were examined in order to comparatively position the investment

\footnotetext{
${ }_{11}$ A special project intending to solve the solid waste problem in Sri Lanka within the next 5 years.

12 Weligama Urban Council has practically adopted composting technology to treat their solid waste.
} 
Management of Municipal Solid Waste in Sri Lanka: A Comparative Appraisal of the Economics of Composting

intensity and the compost productivity of the Weligama model and to understand the scope for further improvement. The study also shed light on possible economically viable strategies towards composting municipal waste in Sri Lanka.

\section{Economics of Composting: A Comparative Assessment}

Yedla and Kansal (2003) have done a critical benefit-cost analysis of composting. They used multivariate functional models based on theoretical considerations concerning all implicit and direct cost items. Figure 2 depicts their benefit-cost model, which details the various costs and benefits related to Municipal Solid Waste Management.

\section{Figure 1: Costs and Benefits Involved in Solid Waste Management}

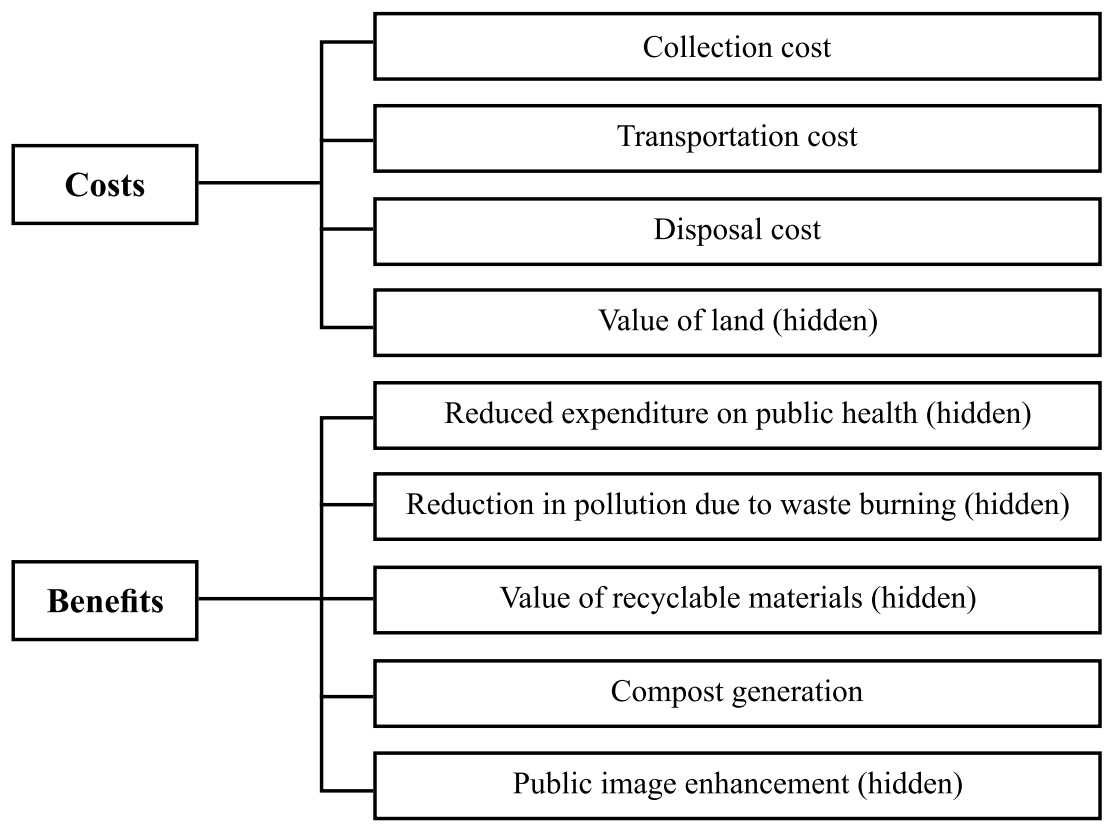

Source: Yedla, S., Kansal, S. (2003). Economic insight into municipal solid waste management in Mumbai: A critical analysis

The perception of the present researchers is that the so-called 'hidden' cost pertaining to land value is a misnomer, at least in the Sri Lankan context. This is because larger extents of productive municipal or semi-urban land would have garbage dumps if no composting operation is in place. In fact, composting helps significantly reduce the extent of waste that 


\section{NSBM Journal of Management}

Vol. 2, No. 1, January - June, 2016

goes to open dumps, thus reducing the area of dumping grounds and increasing dumpsite life. Both have the effect of 'releasing' land that otherwise would be used for open dumps, and the land effect, if considered, is more likely to be a 'hidden benefit' than a 'cost', which, though not straightforward to estimate, could become critically decisive in economically justifying otherwise 'financially unviable' investments on solid waste management.

For the purpose of this research, direct cost and benefit items were addressed in terms of the Sri Lankan context while leaving the 'hidden' elements to be addressed, if necessary, in subsequent research. On the cost side, the total costs of solid waste management operation, including the cost of composting, were taken into account while the economic value of compost output and the salvage value of recyclable material were considered as 'benefits'. The land value saving benefits, waste dumping cost reduction benefits and environmental benefits were thus excluded from the current analysis. The actual net benefits of composting operations therefore are likely to be much greater than what was estimated in this exercise.

The model used in the analysis could be presented in the following equation:

$$
N P V=-1+\sum_{t=1}^{n} \frac{\text { Benifits }- \text { Costs of Operation }}{(1+r)^{t}}
$$

Where, 'I' stands for capital investment. 'Costs of Operation' include all expenses incurred upon reception of waste at the composting plant including those of compost production and disposal of residual garbage, $r$ represents the discount rate, and ' $t$ ' stands for the year starting from the first year of operation $(t=1)$ and running until the end of the life of the plant $(t=n)$

\section{Analysis}

Two models of composting, namely, the 'Weligama Model' (representing the actual experience of composting at the Weligama Urban Council, gathered through the present research) and the Pilisaru Model (representing the standard model stipulated by the Pilisaru Project of the Central Environmental Authority for the same waste handling capacity), were comparatively appraised. Both models were subjected to benefit-cost appraisal, separately from 'financial' and 'economic' perspectives, within the analytical framework depicted in the above model.

According to the Pilisaru Model (implemented since 2009), a composting facility to manage 18 metric tons of municipal waste per day would need Rs. 23 million as initial investment to procure machinery and to construct and develop the facility. The model developed by 
the Weligama UC, on the other hand, was implemented with a capital outlay of Rs. 11 million, and the project was completed by 2011. Moreover, an efficient composting facility should produce at least one-sixth of waste input as compost (Pilapitiya, 2012); ${ }^{13}$ but it was observed that the composting project at Weligama produced only from 1 to 1.5 metric tons per day (approximately 43 metric tons per month) of compost out of a plant with a daily waste handling capacity of 18 metric tons. Therefore, it appears that the Weligama plant, though installed with a much lower capital investment compared to the technical proposal, is managed at much lower levels of output generating efficiency than what could be expected, due most likely to poor waste separation on site. ${ }^{14}$ This also could reflect, at the same time, the scope for further improvement of the Weligama model, initially by improved waste separation on site and subsequently by source segregation of organic matter.

The revenue earned by Weligama UC from the sales of compost amounts to approximately Rs. 370,000 per month, reflecting an average selling price of Rs. 8,500 per metric ton of compost. This UC also salvages nearly three-and-a-half metric tons of recyclable material through their waste separation exercise prior to composting, and earns an average revenue of around Rs. 425 per metric ton by selling such salvaged material, which otherwise would go to the waste dump site.

In appraising economic viability, the foreign exchange savings potential of compost by way of blending with chemical fertilizer was used as the basis as compost produced could significantly reduce chemical fertilizer requirements. Even if one ignores as "unsustainable" the recent scientific finding that boosts (paddy) yield from chemical fertilizer application, there is no debate among scientists that compost enriches the soil and enhances productivity, thereby reducing the use of chemical fertilizer to receive similar yields. For instance, it is estimated that one unit of chemical fertilizer could be mixed with four units of compost and substituted for two to three units of pure chemical fertilizer to obtain similar yields plus better soil conservation. Even if the lower side of the estimate (that is, two units of chemical fertilizer being able to be substituted with one unit of chemical fertilizer plus four units of

\footnotetext{
${ }_{13}$ This estimate, however, could be higher or lower depending on technical parameters such as C:N ratio, temperature, waste segregation, mixing methods, etc., applicable to each given case; which is beyond the scope of this study.

${ }^{14}$ Approximately 3 Metric Tons of compost output should be possible with 18 tons of unsorted waste input, assuming an organic content of approximately 70 per cent of which nearly half is compostable. However, this depends on the quality of unsorted garbage received, and the amount of compost actually produced could be lower if the site level separation does not yield high share of compostable organic content. This could be the cause behind less than expected compost yield observed at Weligama.
} 


\section{NSBM Journal of Management}

Vol. 2, No. 1, January - June, 2016

compost) were assumed, the need for chemical fertilizer would decrease by one unit for every four units of compost. The burden on the public coffers of the associated fertilizer subsidy that could be eased through this 'substitution effect' of chemical fertilizer by compost too was estimated.

Shadow values were used instead of market-based costs and benefits to screen off local market distortions. Shadow Price Conversion Factors of 1.1, 1.2 and 1 were used to convert the market values of investment, variable costs and fixed costs, respectively, in the absence of any formal estimates. The values being greater than or equal to 1 imply a 'net subsidy element' in the economy with regard to such expenses; thus, the resultant viability estimates are likely to be conservative. This is because any variability of shadow prices owing to transfer payments on these cost items on the taxation side would reflect lower economic costs. The entirety of the market value derived from recycled waste, on the other hand, was considered to have full economic value, corresponding to an implicit Shadow Price Conversion Factor of one.

The opportunity cost of funds of $15 \%$ per annum was used in discounting revenue and cost streams in the financial appraisal while a $10 \%$ rate was used in the economic analysis. This is for the purpose of being conservative in the financial and economic viability assessments: a commercial loan could be raised at an interest rate to the tune of $15 \%$, and an environmentally favourable investment, even by a commercial entity, should be able to source the required capital at that rate. ${ }^{15}$ The economic discount factor of $10 \%$ used also is towards the "highside' for the same reasons, and a venture becoming economically viable at such a rate should be acceptable at any lower economic opportunity cost of capital.

\section{Results and Discussion}

The outcomes of the benefit-cost assessment revealed that both models subjected to appraisal are unlikely to be financially feasible for the investing agencies. This might explain why municipal solid waste management through composting is not developed as a commercial venture. However, both management models appear 'viable' from a national economic viewpoint, indicating the potential net benefits the nation could secure through waste composting. The Pilisaru model, in spite of its high capital intensity, offers a higher economic net present value than the management model adopted by the Weligama Urban Council, apparently owing to the latter's poorer productivity in generating output.

15 The analysis was performed in 2013, and the opportunity costs have to be perceived based on the contemporary financial market conditions. 
Management of Municipal Solid Waste in Sri Lanka: A Comparative Appraisal of the Economics of Composting

The results of the benefit-cost assessment are summarised in Table 1 .

Table 1: Summary of Benefit-Cost Appraisal Results

\begin{tabular}{lcccc}
\hline & \multicolumn{2}{c}{ Financial Appraisal } & \multicolumn{2}{c}{ Economic Appraisal } \\
\cline { 2 - 5 } & $\begin{array}{c}\text { Pilisaru } \\
\text { Model }\end{array}$ & $\begin{array}{c}\text { Weligama } \\
\text { Model }\end{array}$ & $\begin{array}{c}\text { Pilisaru } \\
\text { Model }\end{array}$ & $\begin{array}{c}\text { Weligama } \\
\text { Model }\end{array}$ \\
\hline Plant capacity of waste intake & $18 \mathrm{MT} /$ day & $18 \mathrm{MT} /$ day & $18 \mathrm{MT} /$ day & $18 \mathrm{MT} /$ day \\
Investment (Rs Mn) & $23(\mathrm{Mkt}$ & $11(\mathrm{Mkt}$ & $25.3($ Econ & 12.1 (Econ \\
& value) & value) & value) & value) \\
Compost Output (MT/day) & 3 & 1.44 & 3 & 1.44 \\
Variable cost (Rs Mn/Yr) & 3.02 & 1.45 & 3.63 & 1.74 \\
Fixed Cost (Rs Mn/Yr) & 3.42 & 3.42 & 3.42 & 3.42 \\
Net Benefit Flow (Rs Mn/Yr) & 3.29 & 0.086 & 8.35 & 2.52 \\
Net Present Value (Rs. Mn) & $(6.504)^{*}$ & $(10.57)^{*}$ & $26.02 * *$ & $3.37 * *$ \\
\hline
\end{tabular}

Note: (a) *at $15 \%$ discount factor; **at $10 \%$ discount factor

Source: Authors' estimations

The study examined the viability break-even contours of municipal waste composting from financial and economic perspectives, and the relative viability positioning of the two models could thus be comparatively perceived, as depicted in Figure 2.

Figure 2: Break-even Contours Applicable to Municipal Waste Composting

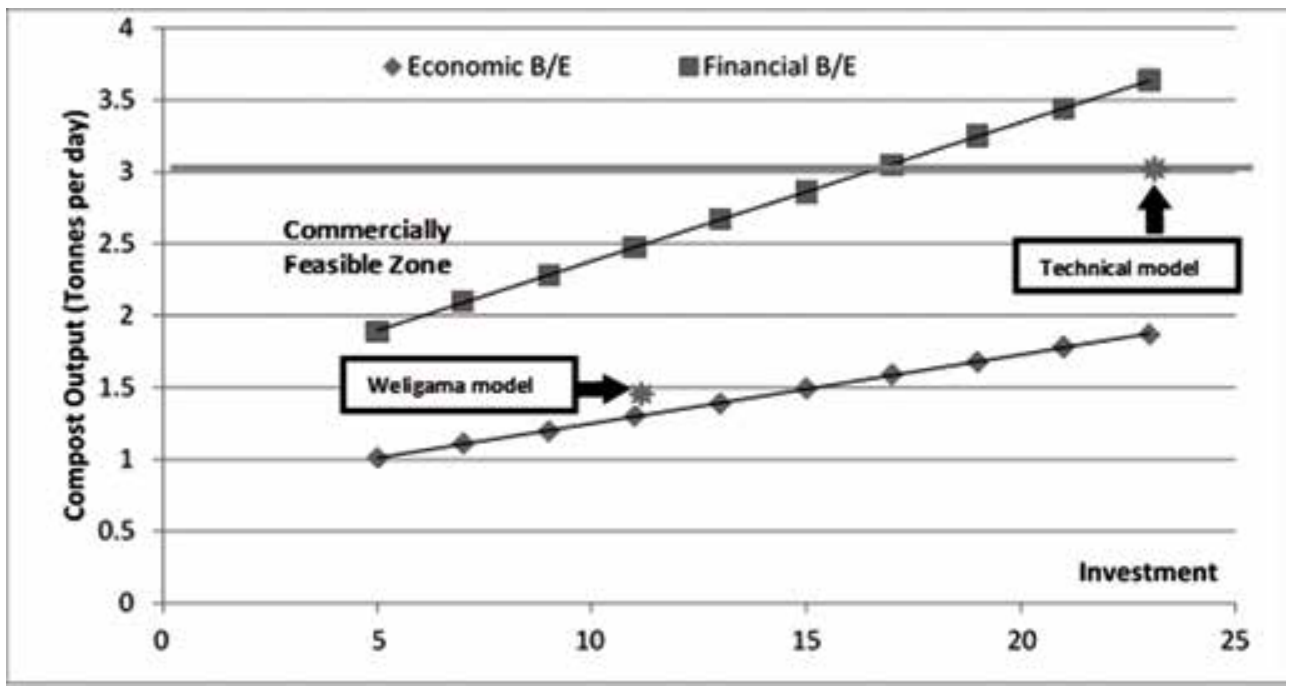

Source: Authors' estimations 


\section{NSBM Journal of Management}

Vol. 2, No. 1, January - June, 2016

This analysis enabled establishing the minimum compost output that would establish the viability of the composting operation at varying levels of initial capital outlays in financial terms. It is clear that both management models (the model adopted by Weligama UC and the Pilisaru model) position themselves above the economic viability break-even contour, but below the financial viability break-even contour. Therefore, while both models are economically justifiable, they are financially unattractive to investors, giving rise to a typical case for state intervention.

The Weligama model, however, offers the possibility of achieving even financial viability as there is ample space in the 'feasible zone' below the maximum output threshold where it could be positioned if the plant's productivity could be improved. For instance, an output level of approximately 2.5 metric tons of compost using 18 metric tons of waste (approximately $60 \%$ increase of productivity, but still $16 \%$ less than the maximum output capacity) would enable the Weligama model to reach the financial viability level. It might be interesting also to note that there is scope for the Weligama model to further increase its investment or variable costs (if it enables better technology or production practices, yielding incremental productivity that more than compensates for the incremental outlays) and still position itself above the financial viability zone. This possibility, however, is non-existent in the Pilisaru model, where the required output level for financial viability lies above the maximum achievable productivity threshold. Local authorities adopting the Pilisaru model will thus require state subsidies, unless they could find a way to reduce initial capital outlay to at least below Rs. 17 million.

Figure 3: Comparative Analysis of Capital Intensities and Yields of Composting Experiments

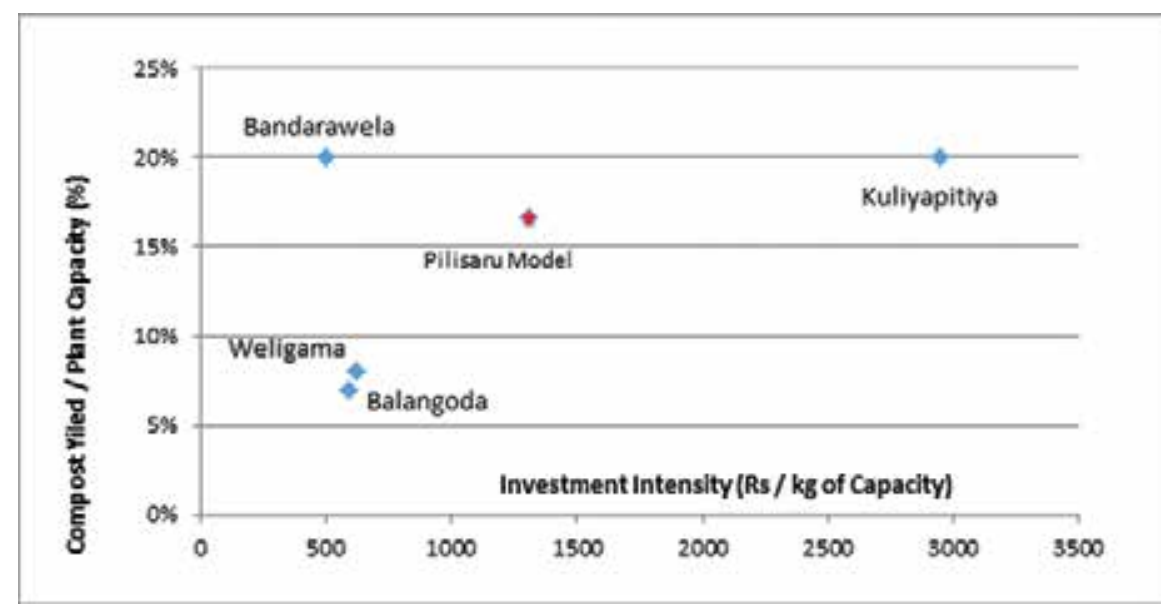

Source: Authors' estimations based on the information gathered through interviews 
Capital intensities and compost yields experienced by several other local authorities in implementing municipal waste composting projects, as comparatively presented in Figure 3, further substantiate the above inferences. ${ }^{16}$ The possibility of the Weligama UC being able to increase its compost yield (from the current level of $8 \%$ of plant capacity) might be indicated by the performance of the Bandarawela and Kuliyapitiya compost plants where, according to the findings of the present research, the compost yield could be as high as $20 \%$ of the waste collected. Though this figure seems to be somewhat optimistic, ${ }^{17}$ and even higher than the estimates of the Pilisaru Model (17\%), it reflects ample scope for further improvement of the Weligama plant. Further, the capital investment intensity of the Weligama plant (Rs. 622 per $\mathrm{kg}$ of waste handling capacity) is approximately $25 \%$ more than that of the Bandarawela plant (Rs. 500 per kg) and slightly higher than even the Balangoda plant (Rs. 590 per kg), indicating the possibility of capital savings in installing compost plants. Thus, the potential for developing a less capital-intensive and a more compost-productive model, leading to achieving 'financial viability' also, cannot be ruled out. In fact, it is highly likely that the facility at Bandarawela works at or above this financial viability threshold. This, however, has to be confirmed through an in-depth investigation of cost structures and benefit streams, to which the present research is not privy.

It is interesting also to note in the above comparative assessment that the plant constructed at Kuliyapitiya is highly investment-intensive. Further investigation into this marked difference from other plants compared in this analysis revealed that it could be due to two possible causes: (a) an apparent over-designing of the Kuliyapitiya plant which only has to provide for 9 metric tons of garbage collection per day, and (b) the development of the Kuliyapitiya plant, according to the stipulations laid down by the Pilisaru design, which consists of a number of building construction activities requiring heavy capital outlays. This latter hypothesis is further supported by the fact that the composting facility at Tissamaharama, constructed with Pilisaru funding, is also highly capital-intensive. ${ }^{18}$ The justification for such a heavy capital outlay becomes questionable when it potentially puts the financial attractiveness of

\footnotetext{
16 The implementation of the projects compared in this study was completed between 2009 and 2011. Thus, the intervention of market price variations and inflation would not be substantial, even though their effect with regard to the financial analysis cannot be excluded. A much closer and detailed investment viability appraisal performed using more refined and updated cost estimates will therefore be necessary if these indicative results are to be used as guidance for planning and implementation of a municipal solid waste composting project.

${ }^{17}$ It is therefore necessary that these estimates are re-validated through further and more intensive research.

${ }_{18}$ As revealed by Dr. Sumith Pilapitiya, a solid-waste management expert and a Consultant to the composting operation at Tissamaharama.
} 


\section{NSBM Journal of Management}

Vol. 2, No. 1, January - June, 2016

these plants out of any reasonable reach, and also because many local authorities appear to have installed and successfully run composting facilities at much less capital intensities. The results of this research therefore tend to suggest that the authorities should revisit the management models and corresponding investment plans of the compost plants that are being considered for funding under the Pilisaru programme in the future.

The study therefore provides evidence to hypothesise that a municipal solid waste management system supported by composting could be viable, not only in terms of national economic and environmental sustainability viewpoints but also in terms of financial viability. In such a scenario, municipal waste management could become a financially self-sustaining activity, which could be undertaken with commercial benefits; the question of public coffers subsidising composting operations then would not arise.

The possibility of an organisation model with private sector investors coming into municipal solid-waste management cannot be disregarded in this context. Given the inherent management efficacy of a commercial venture operation for profit, such a private sector model might be able to achieve the desired investment intensity and compost productivity levels to make the operation financially self-sustaining. If economies of scale are a constraint, the opportunities present in such a "commercial model" to deal with a number of nearby local authorities to source the required waste intake are likely to be significant. Further, some commercial entities might even use their organic waste material to explore this possibility, where super market chains (which might be having significant amounts of vegetables and fruits going out as waste) could possibly be potential entrepreneurs. Such an initiative, on top of their internal financial economics, might even negotiate with the respective local authorities to absorb their garbage at a charge levied on the local authority based on the tonnage so absorbed, or even might offer treatment of such garbage free-of-charge on condition that the waste delivered is sorted and are exclusively non-hazardous organic matter.

On the other hand, the results of this study also could throw light on the feasibility of the Government subsidizing any local authority that is unable to achieve financial viability in composting for some situational or technical reason. Because the Government could save a subsidy of over Rs. 50 on each $\mathrm{kg}$ of reduced consumption of chemical fertilizer and that a kilogramme of chemical fertilizer could be saved through blending with compost at a ratio of 1:4, it should be "expenditure neutral" for the Government to spend up to Rs. 12.50 per kg in support of good quality compost produced for blending with chemical fertilizer. This is approximately $150 \%$ of the current average selling price of Rs. 8.50 per kg recorded by Weligama UC and over ten times the financial gap that has to be met by a subsidy if 
Weligama's financial accounts on composting are to be balanced. Besides, when the compost production capacity of 0.15 million metric tons per year of the 311 local authorities out of their annual collection of nearly one million metric tons of solid waste (NSWMSC, 2008) is considered, the potential chemical fertilizer reduction effect through blending would be approximately 40,000 metric tons and the saving to the public coffers in subsidies otherwise payable on fertilizer would amount to be Rs. 2 billion a year. This could be directed to a dedicated fund, enabling the Government to sustainably administer an effective compost production operation at these local authorities.

\section{Conclusions}

It is evident from the study that composting is a nationally attractive and practically implementable solution to the municipal waste management problem in Sri Lanka. It is technically feasible as successfully demonstrated by the Weligama Urban Council and by a number of other local authorities. ${ }^{19}$ It is also justifiable from the national economic viewpoint as evidenced from the appraisal results of both models subjected to analysis in this study, even without taking into account the environmental and other social benefits associated with it.

Having made an appraisal at different levels of investment and compost productivity, it could be concluded that developing a waste composting model having the potential of reaching even the commercial viability would not be an impossibility. The Weligama management model, for instance, could attain financial viability levels if the compost productivity of its facility could be improved further or if its capital intensity could be lowered, or both. In such a scenario, even a private sector-operated municipal waste management system might not be an impossibility. In that light, the necessity or desirability of state intervention to subsidise composting operations can be questioned as any such assistance might eliminate the incentive for productivity enhancement. Instead, encouragement could be offered for further research and development based on the experiments at the Weligama UC and at other successful local authorities, with a view to arriving at an optimum combination of plant productivity and the required capital outlay.

Regarding the Pilisaru compost management model, the situation is different. No further productivity enhancement could be envisaged as the present appraisal has already assumed

\footnotetext{
19 The plants discussed in this study are still operational with varying degrees of technical and financial efficacy.
} 


\section{NSBM Journal of Management}

Vol. 2, No. 1, January - June, 2016

compost production at the plant's maximum output capacity. Therefore, the Pilisaru model would not be able to reach the financially viable threshold unless its initial investment requirement could be reduced, and thus, the necessity for State assistance would become unavoidable. It could therefore be recommended that the plant facility designs currently used for funding under the Pilisaru programme be improved, particularly with a view to reducing its capital intensity.

On the other hand, the results also demonstrated that the net savings to public coffers would be potentially greater even if compost is manufactured under a calculated subsidy. This is because the savings to the Government by reduced fertilizer subsidy through blending chemical fertilizer with compost would be much higher than the subsidy required for balancing the financial accounts on composting at local authority level.

\section{References}

Asian Institute of Technology, 2004. Municipal Solid Waste Management in Asia, s.1.: A publication of SIDA funded Sustainable Solid Waste Landfill Project.

Bandara, N., 2008. Municiapal Solid Waste Management: The Sri Lankan Case. University of Sri Jayawardenepura, Department of Forestry and Environment Science.

Bandara, N. \& Hettiaratchi, J., 2010. Environmenal Impacts with Waste Disposal Practices in a Suburban Municipality in Sri Lanka. Int. J. of Environment and Waste Management, Volume 6, pp. 107-116.

Glawe, U., Visvanathan, C. \& Alamgir, M., 2005. Solid Waste Management in Least Developed Asian Countries-A Comparative Analysis. s.1., s.n., pp. 5-7.

Hikkaduwa, H. N., Gunawardana, K. W., Halwatura, R. U. \& Youn, H. H., 2015. Sustainable Approaches to the Municipal Solid Waste Management in Sri Lanka. Kandy, Sri Lanka, s.n.

IGES - Kitakyushu Urban Centre, 2011. Establishing a Sound Material-Cycle Society in Sri Lanka: Opportunities and Challenges, Kitakyushu City: IGES - Kitakyushu Urban Centre.

Mahees, M. T. M., Sivayoganathan, C. \& Basnayake, B. F. A., 2011. Consumption, Solid Waste Generation and Water Pollution in PingaOya Catchment area. Tropical Agricultural Research, 22(3), pp. 239-250.

Mannapperuma, N., n.d. Business Opportunities Available in the Waste Management Sector, Colombo: s.n.

NSWMSC, 2008. National Solid Waste Management Status Report 2007, Colombo: NSWMSC.

Pilapitiya, S., 2012. Impacts of Open Dumping and Technical Information on Waste Composting [Interview] (15 October 2012). 
Management of Municipal Solid Waste in Sri Lanka: A Comparative Appraisal of the Economics of Composting

Project Officers, 2012. Estimations of the Pilisaru Project [Interview] (30 October 2012).

Sharholy, M., Ahmad, M., Mahmood, G. \& Trivedi, R., 2008. Municipal Solid Waste Management in Indian Cities-A review. Waste Management, Volume 28, pp. 459-467.

Visvanathan, C. \& Trankler, J., 2003. Municipal Solid Waste Management in Asia-A Comparative Analysis. s.1., s.n., pp. 3-15.

Waste Management Authority, 2013. Survey. s.1.:Waste Management Authority of the Western Provincial Council.

Wijerathna, D. M. C. B. et al., 2012. Solid Waste Generation, Characteristics and Management within the Households in Sri Lankan Urban Areas. Peradeniya, Department of Civil Engineering; University of Peradeniya.

Yedla, S. \& Kansal, S., 2003. Economic Insight into Municipal Solid Wast Management in Mumbai: A Critical Analysis. Int. J. Environmental and Pollution, Volume 19, pp. 516-527. 